\title{
Penal Abolition Praxis
}

\author{
Michael J. Coyle ${ }^{1} \cdot$ Judah Schept $^{2}$
}

Published online: 10 July 2018

(c) Springer Nature B.V. 2018

The present issue of Critical Criminology constitutes the second of three issues on the topic of penal abolition, assembled by us to bring the history and current character of penal abolition research to readers both familiar with and new to such work. The focus of this issue is "Penal Abolition Praxis," and it is preceded by the issue "Penal Abolition and the State: Colonial, Racial and Gender Violences" (Contemporary Justice Review 2017) and will be followed by the issue "Penal Abolition: Challenging Boundaries" (Social Justice 2019). As the editors of the three volumes, we see our work as curatorial rather than prescriptive. Our intent is to provide an intellectually capacious space for diverse epistemological, methodological, and disciplinary approaches to abolition. Taken together, the three issues contribute significantly to the abolitionist project through the cutting-edge work of the featured authors. Articles across the three issues problematize common sense discourses that unwittingly work against abolition; delineate what abolition could look like for particular classes of people in prison, including youth, people with mental illness, and those convicted of sex offenses; explicate the relationships between the carceral state, abolition, racial capitalism, settler colonialism, white supremacy and patriarchy; analyze abolitionist pedagogy; and consider abolition democracy at various scales of the carceral state's expression, including in places where it has heretofore been understudied.

The historical and social production of "crime" has fabricated a theory, a set of practices, and a dominant discourse that collectively is understood as the paradigm of "criminal justice" (Coyle 2013; Hulsman 1997; Mathiesen 2015). This paradigm recognizes a trifle of the transgressions humans complete, labels these chosen transgressions "crimes," and names their chosen actors "criminals" (Bohm 1986; Coyle 2010, 2016; Hulsman 1986). In time, a sprawling "criminal justice" system has been produced, and it is recognizable as the process through which a "criminal" traverses: from law, to police, to courts and finally to prisons. This historic rise has important genealogies and justifications, from the enclosing of the commons (Linebaugh 2014) to the necessity of reinforcing racial capitalist social order following reconstruction (Blackmon 2009; Oshinsky 1996) to the rise of the carceral state as a response to various crises, including multiracial struggles for freedom in the 1960s and 1970s as well as growing surpluses of people and places produced by the changes wrought by neoliberalism. Importantly, these material changes in the state's

Michael J. Coyle

mjcoyle@csuchico.edu

1 Department of Political Science and Criminal Justice, California State University, Chico, Chico, USA

2 School of Justice Studies, Eastern Kentucky University, Richmond, KY, USA 
capacities to arrest, surveil and incarcerate occurred alongside necessary ideological work that naturalized them into a growing carceral common sense (Camp 2016; Gilmore 2007; Hinton 2016).

Essential to the ideological work underwriting the growing carceral state have been the intellectual disciplines rationalizing and promoting theories of "crime" (criminology) and responses to it (criminal justice) in addition to their role in training violence workers (Cohen 1988; Seigel 2018; Schept et al. 2015). This way of seeing, this paradigm, and all the work done in its name, produces an interpretation, or better yet, a logic: the "criminal justice" logic (Coyle 2019). The power of this logic is considerable: it overwhelmingly dominates intellectual circles concerned with transgression ("crime"), conservative as well as progressive political ideology, and consequently, social policy (Brown and Schept 2017). As is everywhere observable (in news media, entertainment formats, and public discourse), the shadow of "criminal justice" logic is almost complete. Thus, our age is one of the carceral society, characterized both by the "anti-state state" (Gilmore and Gilmore 2008), that is, a state organized around police and penal power, as well as the broader circulation of the logic of law, police, courtrooms and prisons.

Against this society stands another imagined one, the post or non-carceral society (Tyson 2014), which much like the slave-free society of antebellum America that existed only in imagination before the abolition of slavery was accomplished, is neither formed nor known. It is still emerging and displaying its commitments. It is one that refuses to ignore that history lives in the present, in that white supremacy, settler colonialism and racial capitalism are inextricable from the origins, logic and practices of "criminal justice" (Davis 2005; Gilmore 2007). It is one that fully recognizes empirical reality in that law breaking is a ubiquitous human behavior that elicits selective responses contingent on historical forces and social order regimes (Coyle 2010, 2016; Hulsman 1986). Finally, it is one that commits to a dismantling of "criminal justice" logic, which includes a thorough accounting of our own internalization and usage of what scholars recently have called "copspeak" (Correia and Wall 2018). Importantly, this includes assessing the complicity of reformist policy and language, grafted as they often are onto the existing material and affective infrastructure of the carceral state.

The guiding logic, praxis and discourse of this non-carceral society is penal abolition, which is an insistent and insurgent argument to abandon "criminal justice" logic and practice (Berger et al. 2017; Coyle 2014; Davis 2003; Davis and Rodriguez 2000). Penal abolition rejects the "criminal justice" paradigm in the total sense that slavery abolitionists rejected the slavery paradigm. Penal abolition insists on the central importance of "criminal justice" to the ongoing work of white supremacy, colonialism, and racial capitalism, contests that the raison d'etre of "criminal justice" is public safety and justice, rejects its essentialist assumptions about human beings, and on empirical grounds repudiates the claim that its practices are effective in responding to human transgressions ("crimes") or promote a society in the interest of all (Coyle 2020). Abolition is a capacious political position, which can include both a focus on community self-determination and the importance of leveraging or taking state power to build an abolition democracy (Davis 2005; Du Bois 1977/1935; Story and Schept 2018). In sum, all of these produce an interpretation, or better yet, a different logic: the penal abolition logic (Coyle 2019). The power of this logic is strong in reason and evidence, though nascent in manifestation: it is not known (or worse, deeply misunderstood) in intellectual circles concerned with transgression ("crime"), is considered naïve and utopian by many, including some on the left (Lancaster 2017) and is consequently not considered seriously in the domain of social policy. With that said, there is evidence of increasing attention to abolition, as demonstrated by debates about it 
in major periodicals (Berger et al. 2017; Lancaster 2017), academic conferences organized around it (the annual International Conference on Penal Abolition, the 2018 Society for the Study of Social Problems meetings), investigative journalists writing about it (Burnish 2017), and organizations like the Black Youth Project 100, the Movement for Black Lives, We Charge Genocide, and others, whose work for reparations, Black freedom and life itself, is grounded in abolitionist theory and practice.

In addition, abolition is both the horizon toward which we work and a framework within which steps toward that horizon can be analyzed, evaluated and then taken or discarded. As the abolitionist Rose Braz argued, "Abolition defines both the goal we seek and the way we do our work today" (Bennett 2008). Indeed, following Braz and the work of the abolitionist movement that she and others stewarded, abolition is both a goal and a practical application of non-reformist reforms (Gorz 1967) aimed at eliminating our reliance on the penal system and building truly democratic capacities grounded in decarceration, a robust social wage, and distributive and transformative justice. When understood as such, we can begin to appreciate that abolitionist work is, in fact, occurring all around us.

The focus of this special issue is praxis and abolition. We use the term praxis intentionally, because its Marxist connotations of theoretical struggle toward social change contrasts with the "practice" orientation of the disciplines (Criminology and Criminal Justice) that we posit are fundamental to the sustaining of "criminal justice" logic (see McLellan 1977, esp. pp. 156-158). This practice, undertaken as it is with a proud commitment to empiricism and science, nonetheless is trapped in empirically unsubstantiated logics that widely miss the point and the problem: what is the meaning, for example, of terms such as "criminal offender," "first arrest," "criminal career," "informal adjustments," or "diversion" in a world of ubiquitous human harm, only some actors of which are targeted by the state, itself at the root of so much violence (see Coyle in this issue)? This approach is broadly unable to perceive the "criminal" justice system as less a response to "crime" (Coyle 2016) than as the state's primary mechanism for managing the conditions constitutive of racial capitalist social order (Gilmore 2007; Story 2018; Story and Schept 2018). And thus, it continues: endless counting of the details of racist/classist/sexist institutions, endless meanderings by endless system workers and endless academics making a living on other peoples' misery and refusing to stop the wheel from going around ad infinitum. The volume of research in Criminology and Criminal Justice dedicated to counting, evaluating, and measuring, all point toward the disciplines' role in the re-formation of the carceral state. Many before us have made this observation. Ned Polsky noted of criminologists that they should admit that they are actually "technologist(s) or moral engineer(s) for an extra-scientific end: making people obey current American criminal law" (1967: 141-142). Writing of the "entirely utilitarian" nature of criminology, Foucault concluded that the discipline and its discourses were "indispensable in enabling [judges] to judge" (1980: 47-48). More recently, Loader and Sparks have noted that even the well-intentioned approach of public criminology falls squarely within the longer tradition of the discipline combining intellectual curiosity "with a reformist ambition of some kind (to prevent crime, rehabilitate offenders, improve the quality of justice, or in some allied way, alleviate avoidable human suffering)" (2010: 771). Along with these scholars, we contend that this "practice" oriented approach of Criminology and Criminal Justice is written into the DNA of these disciplines. As abolitionists suggest, we are ready for an entirely different conception of the matters on hand, and critically, an entirely different praxis.

The articles in this special issue examine how abolition is enacted, embodied and theorized. The authors of these articles offer essential rethinking of common sense logics that plot new ways to theorize and build abolition. The issue thus begins with two essays 
exploring theoretical strands of penal abolition praxis. In the first, Michael J. Coyle proposes a new theoretical approach toward abolition that undermines the theoretical foundations of Criminology and Criminal Justice. Arguing for what he calls "transgression theory" and "standard theory," Coyle's article dislodges calcified assumptions about "crime" and shifts the terrain of the conversation. In the second essay, Liat Ben-Moshe asks "what can abolition teach us about activism?" In engaging abolition as "a political framework, an analysis, an agenda for action...[and] a specific epistemology and an ethical position," Ben-Moshe's essay centers praxis in a capacious consideration of what abolition is.

In the second part of the issue, authors examine penal abolition praxis in five different expressions. In the third article, Adina Ilea asks "what about the 'sex offenders'?" Pushing the boundaries of abolition in essential places, Ilea's article dissects the social construction of the "sex offender" category and considers how abolitionists can and do engage with the problem of sexual harm. In the fourth article, Megan McDowell and Luis Fernandez advance an incisive politics of police abolition, looking specifically at the emergent praxis centered on the call to disband, disempower and disarm the police. Their article goes further, centering abolition in a broader consideration of racial capitalism, liberal reform and alternative democratic practices. In the fifth article, Scott Bowman offers a political and legal analysis toward the abolition of juvenile justice systems. Bowman traces how the American juvenile justice system, despite being conceived "to provide individualized, compassionate assistance to young men and women perceived to be in need of emotional care and/or social control," actually "has produced progressively rational, largely unsympathetic, and increasingly punitive practices." In the sixth article, Liz Bradshaw urges continued collaborative scholarship and activism at the intersections of green criminology and abolition through an examination of toxic prisons. Looking concretely at contemporary sites of toxic prisons, Bradshaw's article builds on foundational work like that of Braz and Gilmore (2006) as well as sounds a call for a more capacious praxis. In the seventh and final article, Lydia Pelot-Hobbs offers a significant contribution to abolition praxis with a meticulous legal and political-economic analysis of the rise of the Louisiana carceral state, paying particular attention to the role of federal intervention. In a formidable dissection, Pelot-Hobbs offers a cautionary tale of the ways that prison reform efforts reliant on federal intervention have ultimately fortified the carceral state. She concludes, however, that abolitionists must be attuned to the points of leverage that may exist at different scales of the state and which can be mobilized to pursue elements of abolitionist reform.

Taken together, these authors expand abolitionist discourse and politics, pointing out existing analytical limitations and exciting new directions. This penal abolition issue along with the other two (Contemporary Justice Review 2017 and Social Justice 2019) are an invitation to engage in further conversation and action.

\section{References}

Bennett, H. (2008). Organizing to abolish the prison-industrial complex. Dissident voice. Retrieved from https://dissidentvoice.org/2008/07/organizing-to-abolish-the-prison-industrial-complex/. Accessed 1 June 2018.

Berger, D., Kaba, M., \& Stein, D. (2017). What abolitionists do. Jacobin. Retrieved from https://jacobinmag .com/2017/08/prison-abolition-reform-mass-incarceration. Accessed 1 June 2018.

Blackmon, D. (2009). Slavery by another name: The re-enslavement of Black Americans from the Civil War to World War II. New York, NY: First Anchor Books.

Bohm, R. M. (1986). Crime, criminal and crime control policy myths. Justice Quarterly, 3(2), $193-214$. 
Braz, R., \& Gilmore, C. (2006). Joining forces: Prisons and environmental justice in recent California organizing. Radical History Review, 96, 95-111.

Brown, M., \& Schept, J. (2017). New abolition, criminology and a critical carceral studies. Punishment \& Society, 19(4), 440-462.

Burnish, C. (2017). It's time to imagine a post-police world-Here's why abolishing the police is not a crazy idea. The free thought project. Retrieved from http://thefreethoughtproject.com/abolishingameri can-police/. Accessed 1 June 2018.

Camp, J. T. (2016). Incarcerating the crisis: Freedom struggles and the rise of the neoliberal state. Berkeley: University of California Press.

Cohen, S. (1988). Against criminology. London: Transaction Publishers.

Correia, D., \& Wall, T. (2018). Police: A field guide. New York, NY: Verso.

Coyle, M. J. (2010). Language, metaphysics and deviancy: Delineating the "evil" "criminal" other. In M. Herzog-Evans \& I. Dréan-Rivette (Eds.), Transnational criminology (pp. 127-144). Nijmegen: Wolf Legal.

Coyle, M. J. (2013). Talking criminal justice: Language and the just society. London: Routledge.

Coyle, M. J. (2014). How prisons became dystopias of color and poverty: Prison abolition lessons from the war on drugs. In S. Bowman (Ed.), Color behind bars (pp. 435-450). Santa Barbara: ABC-CLIO.

Coyle, M. J. (2016). Penal abolition as the end of criminal behavior. Journal of Social Justice, 6, 1-23.

Coyle, M. J. (2019). Utopia and the logics of criminal justice and penal abolition. (Forthcoming).

Coyle, M. J. (2020). Seeing crime: Penal abolition as the end of utopian criminal justice. (Forthcoming).

Davis, A. Y. (2003). Are prisons obsolete? New York, NY: Seven Stories Press.

Davis, A. Y. (2005). Abolition democracy: Beyond prison, torture and empire. New York, NY: Seven Stories Press.

Davis, A. Y., \& Rodriguez, D. (2000). The challenge of prison abolition: A conversation. Social Justice, 27(3), 212-218.

Du Bois, W. E. B.(1977 [1935]). Black reconstruction in America, New York, NY: Atheneum.

Foucault, M. (1980). Power/knowledge: Selected interviews and other writings, 1972-1977. New York, NY: Pantheon.

Gilmore, Ruth Wilson. (2007). Golden gulag: Prisons, surplus, crisis, and opposition in globalizing California. Berkeley: University of California Press.

Gilmore, R. W., \& Gilmore, C. (2008). Restating the obvious. In M. Sorkin (Ed.), Indefensible space: The architecture of the national insecurity state (pp. 141-162). NY: Routledge.

Gorz, A. (1967). Strategy for labor. Boston: Beacon Press.

Hinton, E. (2016). From the War on Poverty to the War on Crime: The making of mass incarceration in America. Cambridge, MA: Harvard University Press.

Hulsman, L. (1986). Critical criminology and the concept of crime. Contemporary Crises, 10(1), 63-80.

Hulsman, L. (1997). Themes and concepts in an abolitionist approach to criminal justice. Retrieved October 2016, from http://hulsmanfoundation.org/wp-content/uploads/2014/07/abolitionistapproach.pdf.

Lancaster, R. (2017). How to end mass incarceration. Jacobin. Retrieved from https://www.jacobinmag .com/2017/08/mass-incarceration-prison-abolition-policing.

Linebaugh, P. (2014). Stop, thief! The commons, enclosures, and resistance. Oakland: PM Press.

Loader, I., \& Sparks, R. (2010). Public criminology? London: Routledge.

Mathiesen, T. (2015). The politics of abolition revisited. New York, NY: Routledge.

McLellan, D. (1977). Karl Marx: Selected writings. New York: Oxford University Press.

Oshinsky, D. (1996). Worse than slavery: Parchman farm and the ordeal of Jim crow justice. New York, NY: Free Press.

Polsky, N. (1967). Hustlers, beats, and others. New York, NY: Lyons Press.

Schept, J., Wall, T., \& Brisman, A. (2015). Building, staffing, and insulating: An architecture Of criminological complicity in the school-to-prison pipeline. Social Justice, 41(4), 96-115.

Seigel, M. (2018). Violence work: Cold War cops across the borders of police. Durham, NC: Duke University Press.

Story, B. (2018). The prison out of place: Mapping carceral power across neoliberal America. Minneapolis: University of Minnesota Press.

Story, B., \& Schept, J. (2018). Against punishment: Centering work, wages and uneven development in mapping the carceral state. Social Justice. (Forthcoming).

Tyson, S. (2014). Experiments in responsibility. Radical Philosophy Review, 17(2), 421-434. 